\title{
CHANGE AND CONTINUITY IN THE MINANGKABAU \\ MATRILINEAL SYSTEM
}

\author{
Tsuyoshi Kato
}

It is said that in Minangkabau society in ancient times, property was given to one's children instead of to one's kemanakan (one's sororal nieces and nephews). ${ }^{1}$ One day, Datuk Katumanggungan and Datuk Perpatih nan Sebatang, the two founders of the Minangkabau adat, wished to go to Aceh. After they sailed out from the port of Tiku/Pariaman on the west coast, the sea suddenly ebbed, for that was the divine decree of God. As a consequence, their ship ran aground on the sand. The two datuk gathered all their children and kemanakan together and said, "Hai, children and kemanakan, let us tow this ship, because it has run aground on the sand." Their children answered, "We are afraid that we will be run over by the ship." Their kemanakan replied, "If that is the wish of our elders, let us tow the ship. It does not matter even if we are run over by the ship and killed in the process, for it is the ship of our elders that has run aground." All the kemanakan then got off onto the sand and pulled the ship. With the assistance of the spirits, the ship floated again of itself and moved to the middle of the sea. Later, following the advice of Cati Bilang Pandai, their able servant, the two datuk decreed that from that time on all the property was to be given, not to the children, but to the kemanakan as a reward of their services. In this way, according to the tambo (traditional "historiography"), did the matrilineal system in Minangkabau society originate.

The Minangkabau of West Sumatra are probably one of the largest matrilineal societies in the world. Aside from the relative rarity of the matrilineal system itself, Minangkabau matriliny has been of special interest to scholars because of its combination there with patrilineally-oriented Islam; "how such a [matrilineal] system could work in conjunction with the patrilineal Islamic legal framework has excited a good deal of speculation."

The seeming contradiction and conflict between adat and Islam has in fact induced many scholars to maintain that matriliny in West Sumatra declined as the Islamization of Minangkabau society progressed. ${ }^{3}$ Two powerful Islamic reformist movements in Minangkabau's recent his tory--the Padri zealots in the early nineteenth century and the Kaum

'The following story is drawn from Datoe' Sanggoeno Di Radjo, Kitab Tjoerai Paparan 'Adat Lembaga 'Alam Minangkabau (Bukittinggi: Sne lpersdrukkerij "Agam," 1919), pp. 95-96.

2Hildred Geertz, "Indonesian Cultures and Communities," in Ruth T. McVey, ed., Indonesia, rev. ed. (New Haven: HRAF, 1967), p. 80.

${ }^{3} \mathrm{Although}$ the process of West Sumatra's Islamization is not clear in detail, the society seems to have been largely converted by the seventeenth century. 
Muda (Young Group) movement early in the twentieth--and their consequences (Dutch political control, penetration of a money economy, educational progress, and increasing population mobility), have generally been perceived as the causes of this purported decline. As early as the middle of the nineteenth century, Francis, a Dutch official in West Sumatra, commented on the "bastardization" of the Minangkabau matrilineal system. ${ }^{4}$ Since then, similar remarks have repeatedly been made by a succession of scholars, including Willinck, Joustra, Schrieke, 5 and de Moubray. ${ }^{6}$ Most recently Maretin 7 has insisted that the Minangkabau matrilineal system is being replaced by a more patrilineally oriented system. Given the changes experienced by Minangkabau society over the last 150 years (including those changes referred to above), his analysis at first may seem plausible.

Till now, unfortunately, there has been too little material published on the contemporary Minangkabau matrilineal system either to substantiate or to refute this diagnosis.8 But I hope here to provide just such material.9 As I hope to demonstrate, matrilineal adat in West Sumatra is far from disappearing, Accommodation to changing circumstance is certainly observable; but the Minangkabau matrilineal system has, contrary to many predictions, managed to survive in health.

The Traditional Minangkabau Matrilineal System

There are four readily identifiable characteristics of the traditional Minangkabau system: 10

${ }^{4}$ E. Francis, "Korte Beschrijving van het Nederlandsch Grondgebied ter Westkust Sumatra 1837," Tijdschrift voor Neerland's Indië, 2, 1 (1839), p. 111.

${ }^{5}$ See the discussion of their comments on the Minangkabau matrilineal system in Hans-Dieter Evers, "Changing Patterns of Minangkabau Urban Landownership," Bijdragen tot de taal-, land-en volkenkunde, 131 (1975), p. 87.

${ }^{6} \mathrm{G}$. A. de Moubray, Matriarchy in the Mazay Peninsula and Neighbouring Countries (London: Routledge and Sons, 1931).

$7 \mathrm{~J}$. V. Maretin, "Disappearance of Matriclan Survivals in Minangkabau Family and Marriage," Bijdragen tot de taal-, land-en volkenkunde, 117 (1961), pp. 168-95.

${ }^{8}$ Two exceptions are Evers, "Changing Patterns," and J. S. Kahn, "'Tradition,' Matriliny and Change among the Minangkabau of Indonesia," Bijdragen tot de taal-, land-en volkenkunde, 132 (1976), pp. 64-95.

${ }^{9}$ Field research was conducted in West Sumatra between January 1972 and May 1974, supported by a grant from the National Science Foundation (\#GS-30173) and a Humanities and Social Sciences Program Fellowship from Cornell University.

${ }^{10}$ In the following description of traditional Minangkabau society and its matrilineal system, I will make frequent use of the tombo. The tambo, originally transmitted orally, but later written down in Arabic letters, is an assortment of origin stories and traditional rules and regulations (hukum adat). The society which the tambo describes is an ideal world; the rules and regulations it propagates are codes of ideal relations and proper conduct. The world of the tambo is nonhistoric, yet at the same time panhistoric; it is not grounded in any historic point in time, yet it is a master plan of how the Minangkabau society should always be. Thus the tambo is something against which Minangkabau society may be judged at any particular time. At the same time, as some reports from the mid-nineteenth century up to the early 
1) Descent and descent-group formation are organized according to the female line. Each village (nagari) consists of several ideally exogamous matriclans, or suku, ${ }^{11}$ which have distinct names, such as Melayu, Piliang, and Caniago. Except for the special case of "adoption,"12 one takes the suku name of one's mother and remains with the same suku for life. A suku itself is usually divided into several matrilineages (payung).

2) A matrilineage is a corporate descent group with a ceremonially instituted male head called the penghulu. He is distinguished by a special title, e.g., Datuk Radjo Adie, which belongs to and stands for his lineage. To address a penghulu by other than his datuk title is a great offense to his lineage members. A lineage possesses communally owned properties, including agricultural land, houses, fish ponds, heirlooms, and miscellaneous adat titles.13 In principle, ancestral property (harta pusaka) is inalienable ${ }^{14}$ and there is no individually

twentieth century show, this master plan was evidently not altogether a dream world. (Many of these reports are referred to in P. E. de Josselin de Jong, Minangkabau and Negri Sembizan: Socio-Political Structure in Indonesia [The Hague: Nijhoff, 1952].)

${ }^{11} \mathrm{Although}$ various scholars and various regions in West Sumatra seem to identify different levels and units of matrilineal groupings within the nagari, I will here discuss only the three levels and units of matrilineal groupings which are essential to the understanding of any nagari in Minangkabau society, i.e., in descending order, suku, payung, and paruik. To define these terms simply, a suku is a group of related lineages who share a common, unknown ancestress; a payung is a group of related adat houses (adat houses will be explained shortly) under the supervision of a lineage head (penghulu); and a paruik is a group of related people generally living in one adat house. It must be kept in mind that these particular Minangkabau terms may also be used in various regions to denote other units and levels of groupings than those discussed here. (On the different meanings attached to these terms, see De Josselin de Jong, Minangkabau and Negri Sembilan, pp.49-55.) But since I am mainly concerned here with understanding the general organization of matrilineal groupings, I shall not refer to exceptions and deviations from the model under consideration. In the subsequent discussion, the English terms $\mathrm{clan}$, lineage, and sublineage are interchangeably used, respectively, for suku, payung, and paruik.

12 Adoption, which requires a proper ceremony, usually takes place when an outsider wishes to become a nagari member. (See Dawis Datoek Madjolelo and Ahmad Marzoeki, Tuanku Imom Bondjol: Perintis Djalan ke Kemerdekaan[Jakarta: Djambatan, 1951], p. 5.) Theoretically, the some 100 suku found in West Sumatra are categorized into four major groups, i.e., Koto, Piliang, Bodi, and Caniago. If the outsider's original suku also exists in the nagari, he seeks affiliation with this suku. Where "his" suku is not available, he is adopted by the suku closest in ancestral relation. (See Rasjid Manggis M. Datuk Radjo Panghoeloe, Minangkabau: Sedjarah Ringkas dan Adatnja [Padang: Sri Dharma, 1971], p. 54.) Adoption for the sake of avoiding lineage extinction does not seem to exist. (Herman Sihombing, "Pembinaan Hukum Waris dan Hukum Tanah di Minangkabau," in Mochtar Naim, ed., Menggali Hukum Tanah dan Hukum Waris Minangkabau [Padang: Center for Minangkabau Studies, 1968], p. 73.)

${ }^{13 \mathrm{~A} 11}$ males are supposed to inherit a lineage adat title upon marriage.

${ }^{14}$ According to adat law, ancestral property may be disposed of under the following conditions, provided that no other financial resources are available and there is unanimous agreement among the lineage members: (1) to repair or rebuild an adat house; (2) to finance the inauguration ceremony of a newly appointed penghulu; (3) to marry off a girl of the lineage; and (4) to provide for the funeral of a lineage member. 
owned property, particularly property of an immovable nature. A lineage is further divided into several sublineages (paruik). These also have their properly recognized male heads (tungganai rumah). Ancestral properties, or, more accurately, rights to their use (ganggam bauntuak), are assigned to sublineages for the benefit of their respective members.

3) The residential pattern is duolocal. After marriage, a husband moves to or near the house of his wife and stays there at night. But he continues to belong to his mother's house and frequently goes back there during the daytime.

4) Authority within a lineage or a sublineage is in the hands of the mamak, not of the father. Mamak literally means maternal uncle, but the term can also refer to classificatory maternal uncles such as penghulu and tungganai rumah. The kin term which complements mamak is kemanakan: it indicates a male ego's sister's children and classificatory kin of the same order.

These general characterizations will become clearer if we look at how family life was actually organized in traditional Minangkabau society. Since daily family life was centered around a rumah gadang (1it. a large house), 15 it is appropriate to begin with a description of this communal dwelling.

An adat house is a rectangular-shaped wooden structure, with its roof curved like buffalo horns. The house is supported by numerous pillars made of ironwood (kayu besi) "which [can] stand for one hundred years."16 The traditional roofing material is palm-fiber, but corrugated iron had already been adopted by many villagers as early as 1907 , according to one travel account. 17 The front side of the house faces east ${ }^{18}$ and is often decorated with colorful carvings, usually of plant motifs. Chickens, goats, and other domestic animals are kept under the raised house floor.

As shown in the accompanying diagram, 19 the adat house consists of two parts. The front half is an open space. It functions as living room, dining room, sleeping quarters for children and occasional guests, and a hall for ceremonies and 1 ineage meetings. In contrast, the back half is partitioned off into smaller compartments. These are the sleeping quarters for female members of the house, especially married or marriageable females, and for their smaller children. Each sleeping compartment, called bilik, is about three meters wide and four meters long. The number of bilik in an adat house varies according to the

${ }^{15}$ Rumah gadang is also called rumah adat (adat house), and this latter term will be used from here on.

16Muhammad Radjab, Semasa Ketjil Dikampung (1913-1928): Autobiografi Seorang Anak Minangkabau (Jakarta: Balai Pustaka, 1950), p. 4.

17Kenji Kiyono, Sumatora Kenkyū (Tokyo: Kawade Shobō, 1943), p. 283.

${ }^{18}$ Ras jid Manggis, Minangkabau, p. 22. However, Muhammad Radjab claims that the house may face either east or west. See his Sistem Kekerabatan di Minangkabau (Padang: Center for Minangkabau Studies, 1969), p. 21.

${ }^{19}$ The chart is drawn from the description of Radjab, Sistem Kekerabatan, pp. 22-23. There may be some variation, such as in the position of the ladders and the location of the kitchen. 
Front

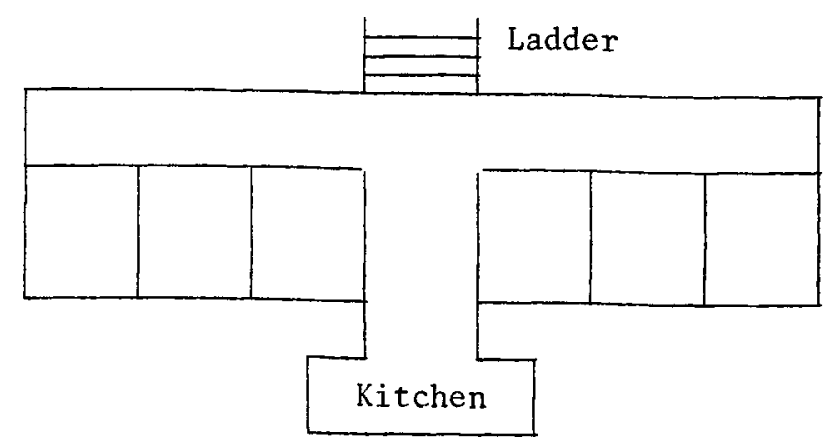

wealth and the proliferation of the sublineage. The largest adat house still standing in West Sumatra measures 120 meters by 15 meters and contains 20 bilik. 20 The average, however, seems to be around seven bilik per adat house. ${ }^{21}$

The adat house was the basic economic unit and the major focus of everyday 1 ife in traditional Minangkabau society. In all likelihood, ganggam bauntuak were given to each adat house.22 As we have seen, ganggam bauntuak is the right to make use of ancestral 1 and and to enjoy its produce; it is not, however, a right of ownership and its division is not an ultimate division--there is no right of disposition.23 Life in an adat house was strongly communal. Most probably, members of the same house cultivated the agricultural land allotted to them together. All produce, mainly rice, was stored in granaries which were shaped like adat houses and were located in front of the house. A proper adat house would have had three rice granaries: one for the daily use of house members, one for feeding guests and passersby, and another for ceremonies and special necessities.24 The communal and corporate nature of traditional life is reflected in a famous Minangkabau adat aphorism:

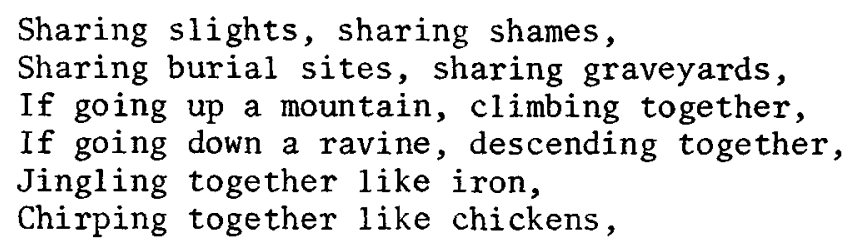

20"Rumah Gadang di Sulit Air," Aneka Minang, 5 (n.d.), p. 9. As far as I know, there has never been a house as large as this outside Nagari Sulit Air.

${ }^{21}$ Umar Junus, "Kebudajaan Minangkabau," in Koentjaraningrat, ed., Manusia dan Kebudajacon di Indonesia (Jakarta: Djambatan, 1971), p. 248.

22De Josselin de Jong, Minangkabau and Negri Sembilan, p. 55.

${ }^{23}$ Rasjid Manggis, Minangkabau, p. 57.

${ }^{24} \mathrm{~A}$. Adnan Sutan Mangkuto, "Masjarakat Adat dan Lembaga Minangkabau" (mimeographed, n.d.), p. 47. 
If there is good news, sent for,

If there is bad news, coming to help. ${ }^{25}$

After reaching marriageable age or upon marriage, a woman was given a bilik in the house. If there was not enough room, it was her mamak's responsibility either to enlarge the house or to build an additional adat house for her. ${ }^{26}$ It was in the bilik that she received her husband at night.

A husband was called (urang) sumando by his wife's family. Sumando is said to originate from the word sando, "to pledge," 27 thus an urang sumando was a person pledged by his suku to that of his wife. He was sometimes 1 ikened to a bull buffalo borrowed for impregnation, 28 and, in many ways, he was not much more than that to his wife's relatives. Usually he visited his wife at night and left her house in the morning. ${ }^{29}$ It was considered acutely embarrassing for both parties if sumando and tungganai met each other in the house. When land was still relatively abundant, the sumando most probably worked on the sawah (wet-rice land) of his own adat house, in addition to cultivating swiddens or upland fields. But as the population became denser and land scarcer, he may have worked on the land of his house or that of his wife's house, depending on the availability of land.

Except for occasional gift-giving on such occasions as the bathing ceremony (turun mandi), ${ }^{30}$ circumcision, and marriage, a sumando's economic responsibility towards his wife and children was minimal.31 The latter were supported by their matrilineage under the supervision of a tungganai.32 Structurally, the basic building block of Minangkabau matriliny was a samandai, meaning "people of one mother," i.e., a mother and her unmarried children. The position of the sumando was not recognized in this "block." Upon the divorce or death of the wife/mother, the children remained at their mother's house and regular personal relationships between father and children ceased to be maintained; ${ }^{33}$ however, the father, or rather the father's sublineage (bako),

${ }^{25}$ In Minangkabau: Sahino, samalu, sapandam, sapakuburan,

Kok ka bukik samo-samo mandaki,

Kok ka lurah samo-samo manurun,

Ba dantjiang bak basi,

Batjiok bak ajam,

Kaba baiak ba-imbauan,

Kaba buruak bahambauan.

${ }^{26}$ De Josselin de Jong, Minangkabau and Negri Sembizan, p. 11.

${ }^{27}$ Radjab, Sistem Kekerabatan, p. 51.

${ }^{28}$ According to Willinck, an urang sumando was like a borrowed animal which initially tends to run away from its new home. See G. D. Willinck, Het Rechtsleven bij de Minangkabausche Maleiers (Leiden: Brill, 1909), pp. 525-26.

${ }^{29}$ De Josselin de Jong, Minangkabau and Negri Sembizan, pp. 10-11.

${ }^{30}$ This is a ceremony for the first bathing of a newborn baby.

${ }^{31}$ A. W. P. Verkerk Pistorius, Studiën over de Inlandsche Huishouding in de Padangsche Bovenlanden (Zlat-Bommel: Noman en Zoon, 1871), p. 43.

32 Ibid., p. 45.

${ }^{33}$ Junus, "Kebudajaan Minangkabau," p. 253. 
still continued a ceremonial gift-giving relationship with the children (anak pisang).34

The precarious position of the husband/father is expressed in a Minangkabau saying: "The urang sumando is like a horsefly on the tail of a buffalo, or 1 ike ashes on a burned tree trunk. [When a little wind blows, it is gone]."35 Even after marriage, the husband continued to belong to the house of his mother. His primary allegiance and responsibility were directed to this group. If he became seriously ill at his wife's house, he would be taken back to the house of his mother for care. ${ }^{36}$ When he died, he was usually buried at the graveyard of his mother's paruik. ${ }^{37}$ It seems that the sumando's rather marginal position in his wife's paruik must have been congruent with the pattern of communal, extended-family living within the adat house under the authority of the tungganai.

In contrast to the sumando's relatively weak position vis-à-vis his children, the most important structural relationship in the Minangkabau matrilineal system was (and is) the one between mamak and kemanakan. After reviewing various Minangkabau kinship terms, Josselin de Jong expressed his surprise that: "The most striking fact that emerges from these tables [of kinship terms] is that the kinship terminology so 1 ittle reflects the very definite matriliny, and almost keeps an even bilateral balance."38 In other words, maternal kin--presumably more important because of matriliny--are not distinguished terminologically from paternal kin. The major distinctions are found between father (bapak) and mother's brother (mamak), and between child (anak) and sister's child (kemanakan). ${ }^{39}$

But in fact, rather than reflecting the lack of "very definite matriliny" as Josselin de Jong suggests, the existence of these distinctions in kinship terminology seems to underline the central importance of the mamak-kemanakan relation, whether blood-related or classificatory, in the structural arrangement of the Minangkabau matrilineal system. The mutual obligations and duties of mamak and kemanakan are regulated by the adat. 40 The mamak is the guardian of his kemanakan and is responsible for their well-being; it is they who will continue the lineage. The mamak is endowed with authority as tungganai or penghulu, and is expected to protect and to increase the matriliny's communal wealth. The essence of Minangkabau matriliny is above all concentrated in the two-generation relationship of mamak and kemanakan.

${ }^{34}$ De Josselin de Jong, Minangkabau and Negri Sembizan, p. 64.

35Zahara Daulay, "Minangkabau: A Preliminary Study of the Culture and People" (M. A. thesis, Cornel1 University, 1960), p. 87.

36Radjab, Semasa Ketjil Dikampung, p. 100.

${ }^{37}$ Edwin M. Loeb, Sumatra: Its History and People (Kuala Lumpur: Oxford University Press, 1972 [originally published in 1935]), p. 118.

${ }^{38} \mathrm{De}$ Josselin de Jong, Minangkabau and Negri Sembizan, p. 44.

${ }^{39}$ The latter distinction applies only to male speakers. For a woman, no terminological distinction is made between her child and her sister's child, for they essentially come from the same womb: both are called anak. A brother's child, however, is anak pisang to his sister.

40For details, see Chairul Anwar, Hukum-Hukum Adat di Indonesia: Menindjau Alam Minangkabau (Jakarta: Segara, 1967), pp. 80-85. 
A11 in a11, the position of the male in traditional Minangkabau society is a strange one in our eyes. He did not own any property, although he might manage it for his sisters and their children. He did not really have a house or a place he could call his own. While still little (probably beginning some time after the age of six or seven), boys slept in the surau (prayer house) where at night they learned how to recite the Koran.41 It was considered shameful for a boy to sleep in his mother's house--if he continued to do so, he was ridiculed by his friends, 42 particularly if there was a marriageable or married sister at home. Though they would return to their mother's houses for meals, boys continued to stay at the surau until they were married. From the day of his departure to a surau, a male ceased to be physically "in" the adat house, even if he stili belonged to it. (The adat house was referred to by the name of a female house member, not by the name of a mamak.43) It remained to him a rumah tunjuk, i.e., a house he could point to as his house of origin; but the house itself was for his mother and sister. ${ }^{44}$ In old age, should a man's wife have already died, or should he be divorced, he had once again to live in a surau.45 After marriage, he was only a visiting guest at his wife's house. There are many indications that even in his house of origin, internal, day-to-day affairs were in the hands of the women rather than in those of the mamak.46 This relative lack of roots must have been all the more the case for those mamak who did not have any position as tungganai, penghulu, or other adat functionary. The men's world in traditional Minangkabau society thus consisted of the surau (prayer house), the mosque, the lapau (coffee house), the balai (council hall) and the dangau, 47 all of which appeared peripheral and temporary by comparison with the solidity and security of the adat house.

Society in Transition

The Dutch first came to West Sumatra in the early seventeenth century. Their primary interest was in the pepper produced in the southern part of the region (e.g., Menjuta). Their influence, however, was largely confined to several port towns. The penetration of Dutch sovereignty into the interior of West Sumatra was delayed another two centuries. The Padri wars, initiated by a militant reformist movement in the early nineteenth century and eventually developing into civil war, brought direct Dutch intervention to the whole of West Sumatra.

${ }^{41}$ Radjab, Semasa Ketjil Dikampung, p. 21; Harsja Bachtiar, "Negeri Taram: A Minangkabau Village Community," in Koentjaraningrat, ed., Vilzages in Indonesia (Ithaca: Cornell University Press, 1967), p. 359.

${ }^{42}$ Ahmad Datuk Batuah, with the assistance of A. Datuk Madjoindo, Tambo Minangkabau dan Adatnja (Jakarta: Balai Pustaka, 1956), p. 148.

${ }^{4{ }^{3} \mathrm{H}}$. Mansur Datuk Nagari Basa, "Hukum Waris dan Tanah dan Peradilan Agama," in Menggali Hukum Tanah, p. 131.

${ }^{44}$ Hamka [Haji Abdul Malik Karim Amrullah], "Adat Minangkabau dan Harta Pusakanja," in Menggali Hukum Tanah, p. 30.

45Radjab, Semasa Ketjil Dikampung, p. 21; Hamka, "Adat Minangkabau," p. 37.

46Daulay, "Minangkabau," pp. 64-65; Loeb, Sumatra, p. 106; Rasjid Manggis, Minangkabau, pp. 56, 64; Bachtiar, "Negeri Taram," p. 368.

${ }^{47} \mathrm{~A}$ dangau is a small hut built at the edge of a field to shelter those guarding the crops. 
The consolidation of Dutch control resulted in two important changes in Minangkabau society relevant to the present discussion. One was rapid population growth, and the other was the proliferation of a money economy. As in Java, the population in West Sumatra grew rapidly under the Pax Nederlandica. Although reliable figures for the nineteenth century are difficult to obtain, one estimate indicates that the population of West Sumatra nearly tripled between 1852 and 1930 , from 690,000 to $1,900,000.48$

The rapid advance of the money economy was no less impressive. Cash crops, e.g., coffee, rubber, and various spices, were introduced. Handicrafts, probably hitherto mainly for home consumption, became commercialized enterprises. Itinerant petty traders, middiemen, and pedati49 drivers, all natives, began to play such an important role in the economy that the Dutch authorities were seriously alarmed that they would cut into the profits of the government.50 The expansion of the colonial bureaucracy created salaried indigenous people, such as school teachers and lower government officials. The introduction of a monetary tax in the early twentieth century accelerated this trend still further.51

The impact of these changes on the matrilineal system is not too difficult to understand. As the population grew, ancestral property became increasingly inadequate to support al1 the members of an adat house. By the middle of the nineteenth century, overcrowded villages in the interior had nearly exhausted their frontiers for agricultural expansion. Trapped as they were within the boundaries of the nagari, villagers found that the money economy opportunely presented them with attractive alternatives. For the money economy created sources of livelihood not restricted by regulations on ancestral property; "selfearned" property (harta pencarian) usually came in the form of cash earned from office work or from commercial or artisanal activities.

Change and Continuity in the Minangkabau Matrilinea1 System

One clear change in the Minangkabau family system resulting from the factors listed above has been that conjugal and father-child ties assumed increasing importance. As ancestral property became inadequate, wives began to rely on the self-earned property of their husbands as supplementary sources of livelihood. The primary economic unit in society was now more likely to be the conjugal nuclear family than the samandai or paruik. The husband began to reside permanently in the house of his wife. The "sumando batandang" (visiting husband)

${ }^{48}$ E1izabeth E. Graves, "The Ever-Victorious Buffalo: How the Minangkabau of Indonesia Solved Their 'Colonial Question'" (Ph.D. dissertation, University of Wisconsin, 1971), p. 24; Volkstelling 1930, 4 (Batavia: Departement van Economische Zaken, 1933), p. 114 .

${ }^{49} \mathrm{~A}$ buffalo-drawn cart for the transportation of goods.

50Graves, "The Ever-Victorious Buffalo," pp. 204-6.

51B. Schrieke, "The Causes and Effects of Communism on the West Coast of Sumatra," in his Indonesian Sociological Studies: Selected Writings of B. Schrieke, Part I (The Hague: van Hoeve, 1955), pp. 95-99. 
was gradually transformed into the "sumando menetap" (1iving-in husband).52 This physical proximity was essential to the psychological proximity required for stabilizing the conjugal nuclear family. Reflecting the closer ties developing within the nuclear family, men increasingly transferred their harta pencarian to their children by means of hibah (gift), 53 lest it fall into the hands of their kemanakan upon their deaths. This practice became particularly popular in the early twentieth century; ${ }^{54}$ today it is the general custom that harta pencarian is inherited by a man's children.

While harta pencarian was the basis for the emergence of the nuclear family as the primary economic unit, the increasing popularity of relatively small non-adat houses was the physical basis for accommodating the nuclear family as a residential unit. Today, the adat house, which symbolized the Minangkabau matrilineal system, is no longer common. According to a survey I conducted in four villages near Bukittinggi, around the turn of the century 70 percent of village dwellings were adat houses; the figure now is only 13 percent. Modernstyle and single-household houses are massively predominant.

The shift to a more closely knit conjugal tie is reflected in the decline of polygamy and divorce rates. According to the 1930 Dutch census, West Sumatra had the highest numbers of male and female divorcees per 100 adult persons in the entire Netherlands East Indies: 9.8 and 14.2 , respectively. The second highest figure for males was 7.2 (Sumatra's East Coast) and for females 10.2 (West Java). Likewise, men in West Sumatra were most frequently polygamous: 8.7 persons per 100 married men, compared to the second highest figure of 7.7 for "Timor en onderhoorigheden." 55

According to my survey, however, while 78 percent of the fathers of the 395 respondents in the four villages that I studied had had the experience of polygamy, the figure was only 38 percent for the respondents themselves. A similar decrease was observable in divorce.56

The decline in both was partly the result of attacks, beginning in the early twentieth century, by Islamic reformists and Westerneducated intellectuals.57 The Kaum Muda, seriously concerned with the

52 Iskandar Kemal, Sekitar Pemerintahan Nagari Minangkabau dan Perkembangannja (Padang: Pertjetakan Daerah Sumatera Barat, 1964), pp. 222-23.

53The Arabic term for the gift of one's property to a designated person while one is still alive. Gifts given under hibah cannot be contested by one's heirs.

${ }^{54} \mathrm{De}$ Josselin de Jong, Minangkabau and Negri Sembilan, pp. 115-16.

55Volkstelling 1930, 8, pp. 104, 106.

56 Since my survey used differing methods to investigate divorce rates, it is not possible to give comparative divorce rates between the 395 respondents and their fathers. However, I roughly estimate that the divorce rate is 22 percent among the present generation and 47 percent among the previous generation. For more details, see Tsuyoshi Kato, "Social Change in a Centrifugal Society: The Minangkabau of West Sumatra" (Ph.D. dissertation, Cornell University, 1977), pp. 233-34. The wide discrepancy between the 1930 census and my survey results is due to the face that the former only refers to current civil status while the latter refers both to current status and past experiences.

57Anwar, Hukum-Hukum Adat di Indonesia, p. 113. 
education and emancipation of women, admonished men not to divorce their wives lightly and stressed the strict conditions for polygamy (e.g., equal treatment of wives) required by true Islamic teachings. The opinions of Western-educated intellectuals on marriage were most eloquently expressed in the popular novels written by Minangkabau authors in the $1920 \mathrm{~s}$ and 1930s. The main themes of these novels were the importance of love, the value of the conjugal tie, the undesirability of the practice of urang jemputan (by which a man was "paid" to marry a girl), the father's economic responsibility towards his wife and children, and sympathy for women's plight in contemporary society.58

Despite these changes, which seem to indicate the increasing importance of the nuclear family as an economic, residential, and psychological unit within the Minangkabau matrilineal system, many of the latter's features have remained relatively unchanged. This case can be best understood if we refer to the four main characteristics of the Minangkabau matrilineal system mentioned earlier, namely, (1) descent and descent group formation are organized according to the female line; (2) a matrilineage is a corporate descent group; (3) the residential pattern is duolocal; and (4) authority is in the hands of the mamak.

of these characteristics, the first has basically survived unchanged. Suku and matrilineage still exist and function in society. A person's suku name is still an important part of his or her identity whether in the village or in wider circles. People are still often addressed or referred to in the village by their matrilineally derived adat titles or by their suku names. Beyond the village, various government documents in West Sumatra require identification by suku name together with personal name. Some form of suku exogamy is still strictly observed.

As for the other three characteristics of Minangkabau matriliny, there have been considerable changes, as described above. However, a closer scrutiny of these changes reveals, as I will try to show, that they do not necessarily jeopardize the matrilineal system itself.

With regard to the matrilineage surviving as a corporate group, we may note that ancestral property remains extremely important. Although such property, and above all land, is now likely to be "divided" among nuclear families, it is "inherited" in a pattern that is essentially unchanged: it is transmitted according to the female line and is in principle inalienable from the matrilineage or sublineage. At the same time, the increase in self-earned property has added complexity to "inheritance" practices. It has been already pointed out that, in contrast to ancestral property, self-earned property can be and is inherited by a man's children instead of by his kemanakan. However, this discretion in the disposition of self-earned property is strictly confined to a single generation. The reason for this is interesting. As we have seen, Minangkabau adat basically distinguishes between two types of property, ancestral and self-earned. Ancestral property belongs to the lineage and is handed down according to matrilineal principles over generations (turun temurun); self-earned property is acquired by a man's own effort and thus may be given to a person or persons of his choice. Such a classification (and conceptualization)

${ }^{58}$ For example, see Marah Rusli, Sitti Nurbaja: Kasih Tak Sampai (Jakarta: Balai Pustaka, 1965 [originally published in 1922]). 
does not recognize an idea of a type of property which may be inherited from generation to generation with each generation having discretionary disposal rights over it. Self-earned property, especially nonmobile property such as houses and land, reverts to the status of ancestral property in two or three generations even where it is initially bequeathed to a man's children. Not only is the general status of selfearned property generation-bound, but nonmobile self-earned property tends to be bequeathed to daughters in preference to sons, 59 and from them to their daughters and so on according to the matrilineal principle. Self-earned property inherited by sons rather than by daughters is also likely to be given to daughters alone in the grandchildren's generation (counted from the original owner of the property) and from then on to their daughters following the female line. It is evident, then, that, so long as these principles are retained, sizeable amounts and proportions of self-earned property cannot be accumulated in the patriline over generations. Even in Padang, the provincial capita1 and the largest urban center in the province, the proportion of registered individual 1 and--the approximately 40 percent of the total 1 and in the city formerly under Dutch ownership and now controlled by Chinese--has remained virtually stable for the last fifty years. The remaining 60 percent is unregistered; these lands seem to remain locked into the cycle of self-earned to ancestral 1 and. 60

Coupled with the increasing importance of self-earned property, the practice of bequeathing such property to children has misled some scholars into either pointing out or predicting the dissolution of ancestral property, and thus the dissolution of matrilineage, and even of the Minangkabau matrilineal system itself. None of this, in fact, is actually happening. The corporate nature of ancestral property, albeit in a more flexible form, is still very strong.

Aśs suggested earlier, residential arrangements are now more properly identified as uxorilocal than duolocal. A husband may still visit his mother's house rather regularly (e.g., once a week), particularly if his wife's house is nearby, in order to keep informed of the situation at his natal home. Nevertheless, with his time mostly spent at his wife's house, his life (though not kin affiliation) belongs there rather than to his mother's. The pervasiveness of uxorilocal residency is clear from my survey in the four villages near Bukittinggi. Among 395 houses, there were only five cases where a wife had moved to the house of her husband. These rare cases were generally explained in terms of expediency.

Although the shift from duolocal to uxorilocal residence has altered the nature of a man's relation to the matrikin of his wife (as will be explained below), this shift does not in itself necessarily mean that Minangkabau society has become less matrilineal.61 In uxori-

\footnotetext{
$59 \mathrm{Kahn}$, "'Tradition,' Matriliny, and Change," p. 73.

${ }^{60}$ Evers, "Changing Patterns." Since Evers cites only two cases of diachronic data, further study is necessary to substantiate this contention.

61According to David Aberle's study, uxorilocal or matrilocal residence is modal (49 percent) for his sample of 84 matrilineal societies from different parts of the world; only 4 percent are duolocal. David F. Aberle, "Matrilineal Descent in Cross-Cultural Perspective," in David M. Schneider and Kathleen Gough, eds., MatriZineal Kinship (Berkeley: University of California Press, 1961), p. 667.
} 
local residence patterns, as in duolocal, women still remain with their matrilineal relatives after their marriage. Not only are households still basically formed around women and the network of their matrikin, but the ideology (and the practice) that the house essentially belongs to the lineage of its females remains strong. Thus the custom of boys sleeping in surau (and now sometimes in coffee shops and in empty houses) is still commonly practiced.

One concomitant of uxorilocal residency is the increasing involvement of the husband with the matrikin of his wife. Previously, a man's socioeconomic obligations to his children, let alone to his wife's relatives, were very limited (e.g., intermittent gift-giving on ceremonial occasions). Uxorilocal residency was both a cause and a consequence of closer ties between a man and his wife and children. It also entailed more frequent contact between a man and his wife's kinsmen and the former's growing involvement in the welfare of the latter. Nowadays, it is very common for a husband, especially if he has his own sources of income, to be expected to make some kind of economic contribution to his wife's matrikin (e.g., helping to send his wife's nephew to school). Tanner is even of the opinion that the focus of a man's involvement is increasingly shifting from the matrifamily of orientation to the matrifamily of procreation.62 This contention may be a little exaggerated, but there is no doubt that a man's socioeconomic obligations are no longer directed solely to his own matrilineage; that of his wife can also become very demanding.

In addition to the confusion over ancestral and self-earned property, much of the misunderstanding about the present Minangkabau matrilineal system concerns the sphere of authority. Some people argue that since the solidarity of the nuclear family is strong and since the father, not the mamak, takes care of the children, the matrilineal system must have been replaced by a patrilineal or bilateral system. This interpretation is clearly inaccurate. For here the distinction between authority within the domestic group and authority within the descent group is crucial.63 The descent group we are concerned with is a group defined by the matrilineal principle, corporate property, and an appointed leadership; the domestic group, on the other hand, is a household which handles the care of children.

Previously, both the domestic group and the descent group were formally under the authority of one person, the tungganai; in practice, it is probably more accurate to say that the domestic group was to a great extent under the authority of the oldest woman in the adat house.64 Today the father and the mother are primarily responsible, although it is not unusual for them to be assisted by the mamak ${ }^{65}$ in

62Nancy Tanner, "Minangkabau Disputes" (Ph.D. dissertation, University of California at Berkeley, 1971), p. 34 .

${ }^{63}$ For more details see David M. Schneider, "Introduction: The Distinctive Features of Matrilineal Descent Groups," in Matrilineal Kinship.

${ }^{64} \mathrm{See}$ footnote 46.

${ }^{65}$ For example, according to Naim's research, about 50 percent of some 150 penghulu surveyed answered that they were currently taking care of their kemanakan. Mochtar Naim, Penghulu di Minangkabau, University of Singapore, Department of Sociology Working Papers, No. 14 (Singapore, 1973), p. 16. 
looking after the material welfare of their children. The mamak is by no means completely left out of the domestic group sphere. He is kept informed of what is happening to his kemanakan: their educational plans, their occupational plans, and their plans for migration, not to mention marriage.

In the sphere of the descent group, all adat matters which deal with the lineage as a corporate group are the concern of the mamak. Decisions related to ancestral properties and the conduct of lineage members are made by the matrilineage as a whole under the guidance of the mamak. Examples of such decisions concern disputes over ancestral property and titles, infringements of adat customs, and misbehavior by 1 ineage members. A husband may be consulted in these matters, but final authority is unquestionably in the hands of the mamak.

The mamak still plays an important role in the marriage arrangements of his kemanakan. Even if he is not directly involved in seeking a prospective spouse, it is customary to ask the permission of the mamak before marriage. Courtesy aside, this custom has its practical aspects. All adat ceremonies are arranged by the mamak--the protocol, the exchange of speeches, and so forth. Marriage is usually celebrated by two rituals, the adat wedding ceremony and the nikah wedding ceremony. The former symbolizes Minangkabau matriliny and the role of the mamak, while the latter symbolizes Islamic law and the role of the father--for in Islamic $1 \mathrm{aw}$, the father of the bride is the principal witness to the marriage. The adat wedding ceremony is preceded by the nikah, but without the former the marriage is not considered legitimate.66 The mamak's consent to the marriage is thus crucial, for without it no speaker will appear for the adat ceremony and, as a consequence, it will not take place.

Naturally, these two spheres of authority are not always clear cut. (When I was conducting interviews in the villages, I would ask for the "head of the family" (kepala keluarga) at the houses I visited. In turn, I was often asked by the husband, now staying at his wife's house most of the time, which head of the family I meant, the sumando or the mamak.) Sometimes an attempt is made by one side to venture into the other's sphere, yet people are always clearly aware of the conceptual distinction.67

\section{Conc1usion}

In sum, there have certainly been significant changes in the Minangkabau matrilineal system. The increasing importance of the nuclear family as an economic and residential unit is undeniable.

${ }^{66}$ The adat ceremony is far the more expensive of the two. Thus it can happen that the adat ceremony is postponed for some time after the nikah rite until it is economically feasible. Even in these instances, it is rare, particularly in the village, for consummation of the marriage to take place before the adat ceremony is carried out.

67 It may be helpful to conceive of domestic group authority and descent group authority as parts of a continuum rather than as discrete categories. At opposite ends of the continuum the preeminence of the mamak or the father is relatively clear. But as one approaches the middle of the continuum, the distinction becomes blurred and potential conflicts between mamak and father may emerge. 
Concurrently, the bonds between husband and wife, and between father and children have obviously been growing. Yet it is premature to suggest the disappearance of the matrilineal system itself.

It is true that some educated Minangkabau men in the cities now pass on part of their names to their children as the "family name." However, the principle of matrilineal descent reckoning is still practiced in West Sumatra, and suku affiliation still plays an important role in terms of establishing a person's identity and determining the range of possible marriage partners. Property is now given to children instead of kemanakan, but only self-earned property. Residential arrangements are now more uxorilocal than duolocal. But these changes do not seriously jeopardize the matrilineal system. The father wields strong influence over the lives of his children, but only in the sphere of the domestic group; the mamak still dominates the sphere of the descent group. If we observe the balance struck between change and continuity in the Minangkabau matrilineal system, we are 1 ikely to be impressed by how successfully the system has managed to survive by accommodating to changing times and circumstances.

This accommodation is all the more remarkable when we consider the extent of the transformations the Minangkabau village has experienced since the turn of the century. In the villages that I studied, only 13 percent of the male population attended any kind of formal school at the turn of the century. Now, over 95 percent do so, and 33 percent of them go on to senior high school or further. Around the turn of the century, 27 percent of the males had had the experience of out-migration, while among the present generation, the figure is 89 percent. Seventy-four percent of the males at the turn of the century were engaged primarily in agriculture; only 15 percent among the present generation are so occupied.68

Despite these notable changes, the Minangkabau matrilineal system continues to maintain its basic features. The theme of the "disintegration of Minangkabau matrilineal system" has had a long history, starting with Francis in the early nineteenth century. But as a wel1known Minangkabau saying goes:

01d adat, ancient heritage, Neither rots in the rain, Nor cracks in the sun.69

It is easy to point out the continuity of the Minangkabau matrilineal system; it is a different matter to answer the questions of why and how the system has been able to survive so far. I have addressed myself to this question elsewhere.70 I believe that the famed merantau (out-migration) activities of the Minangkabau are closely connected with their society's dynamism, i.e., a curious mixture of flexibility and conservatism.

${ }^{68}$ These figures include both villagers and current migrants from the four villages surveyed.

69 In Minangkabau: Adat lamo, pusako usang,

Indak lapuak dek udjan,

Indak lekang dek paneh.

70Kato, "Social Change in a Centrifugal Society. 
Historically, one can discern three stages of Minangkabau merantau activities. In the earliest era, the population moved in segmental groups from the darek (interior) to the rantau (outer areas) in search of virgin lands because of population pressure in the interior. As the frontier was pushed further and further away from the interior, and as the outer areas became relatively crowded, a new mode of individualistic merantau became more important than village segmentation. Since the end of the nineteenth century, commercial activities have flourished in many parts of Sumatra--plantations in East Sumatra, rubber in Central Sumatra, and oil in South Sumatra. It was into these areas that "superfluous" Minangkabau males made the long migration in search of wealth. (Previously, such individual migration was seasonal and of a short duration, and families were generally left behind in the village). After World War II, merantau has become a movement of (nuclear) families rather than of individuals. Migrants tend to stay away from villages for longer periods and return only rarely. Merantau Cino or migration like the Chinese (many of whom never went back to China from Southeast Asia) is more prevalent. Energetic and progressive people tend to leave the villages, while the less energetic and less progressive stay on.

I will not go into the details of my argument here. It is sufficient to point out that merantau and the persistence of matriliny are integral parts of the historical process in Minangkabau society.

Matrilineal adat remains strong and survives, albeit with accommodations, because of merantau. It is as if by dispersing populations in different fashions, merantau at each historical stage provided the means for successfully maintaining Minangkabau matriliny. 